Gut, 1967, 8, 435

\title{
Primary sclerosing cholangitis, the biliary tree, and ulcerative colitis
}

\author{
M. E. C. THORPE, P. J. SCHEUER, AND SHEILA SHERLOCK \\ From the Departments of Medicine and Pathology, Royal Free Hospital, London
}

EDITORIAL COMMENT It is well known that ulcerative colitis may be associated with a number of different diseases of the liver. This paper records sclerosing cholangitis as one possible mechanism of intrahepatic cholestasis. Sclerosing cholangitis is a general disease of the biliary system involving intra- and extrahepatic ducts and also the gall bladder. The diagnosis can only be made by laparotomy. The prognosis seems to be better that was originally thought.

Ulcerative colitis may be associated with a number of different diseases of the liver and biliary tree. These include fatty liver, active chronic hepatitis, cirrhosis (Holdsworth, Hall, Dawson, and Sherlock, 1965), and coexisting conditions such as virus hepatitis. The most common hepatic complication of ulcerative colitis, however, is intrahepatic cholestasis. This is covered by a variety of names including pericholangitis (Mistilis, 1965), interlobular hepatitis (Kimmelstiel, Large, and Verner, 1952), intrahepatic cholangiolitic hepatitis (Schwartz and Dale, 1958), and triaditis (Stauffer, Sauer, Dearing, and Baggenstoss, 1965). Inflammation of the larger bile ducts within as well as outside the liver has been described as primary sclerosing cholangitis (Schwartz and Dale, 1958; Holubitsky and McKenzie, 1964). This may be associated with diseases other than ulcerative colitis, including retroperitoneal fibrosis and Riedel's struma (Bartholomew, Cain, Woolner, Utz, and Ferris, 1963). Ulcerative colitis may also be complicated by a carcinoma arising in a major bile duct (Stauffer, et al., 1965; Rankin, Skyring, and Goulston, 1966).

The present paper describes four cases of ulcerative colitis with primary sclerosing cholangitis and emphasizes the variable involvement of ducts of all sizes, whether intrahepatic or extrahepatic, and also of the gall bladder.

\section{CASE REPORTS}

CASE 1 In 1963, this 32-year-old draughtsman developed diarrhoea which has continued intermittently. Motions number at least four daily, and blood and mucus are present during exacerbations. A barium enema performed in 1964 was not diagnostic of ulcerative colitis but appearances at sigmoidoscopy in April 1966 were consistent with severe ulcerative colitis.

In May 1964, jaundice appeared with complaints of nausea, vomiting, fever, and itching, and several episodes of epigastric pain. Stools were pale. Serum bilirubin was $12.2 \mathrm{mg}$. per $100 \mathrm{ml}$. and serum alkaline phosphatase 20 King Armstrong units per $100 \mathrm{ml}$.: jaundice persisted and in July 1964 laparotomy was performed. The common bile duct was considerably thickened and contained pultaceous material. The gall bladder and pancreas felt normal; the liver was slightly enlarged but no lesion was noted macroscopically. Staph. albus only was grown from a liver biopsy. Histological examination of a biopsy of the thickened bile ducts revealed dense fibrosis with patchy infiltration by lymphocytes, plasma cells, and eosinophils. No tumour was seen. The liver changes (Fig. 1) were those of a subacute hepatitis with much cholestasis, and were not those of uncomplicated biliary obstruction. Both portal zones and parenchyma contained an infiltrate which included many plasma cells. Centrilobular liver cells were swollen and mild fatty change and slight septate fibrosis were also present.

The patient improved with prednisolone and ampicillin. Apart from frequent stools, he was well until May 1965, when he again developed jaundice and griping abdominal pain, which lessened after a course of ampicillin. A recurrence of cholestatic jaundice with pyrexia and abdominal pain led to a further laparotomy in July 1965, at which time the common bile duct was found to be a thickened, fibrous cord. All the extrahepatic ducts were involved. An operative liver biopsy showed fatty change and only very mild inflammation. Fibrosis had not progressed, and bile ducts again appeared normal. Cholestasis was absent.

Since the second operation, the patient has had seven further episodes of cholangitis accompanied on six occasions by exacerbations of the colitis. These episodes have occurred despite prophylactic steroids and antibiotics, but to date have responded to increased steroids and/or 


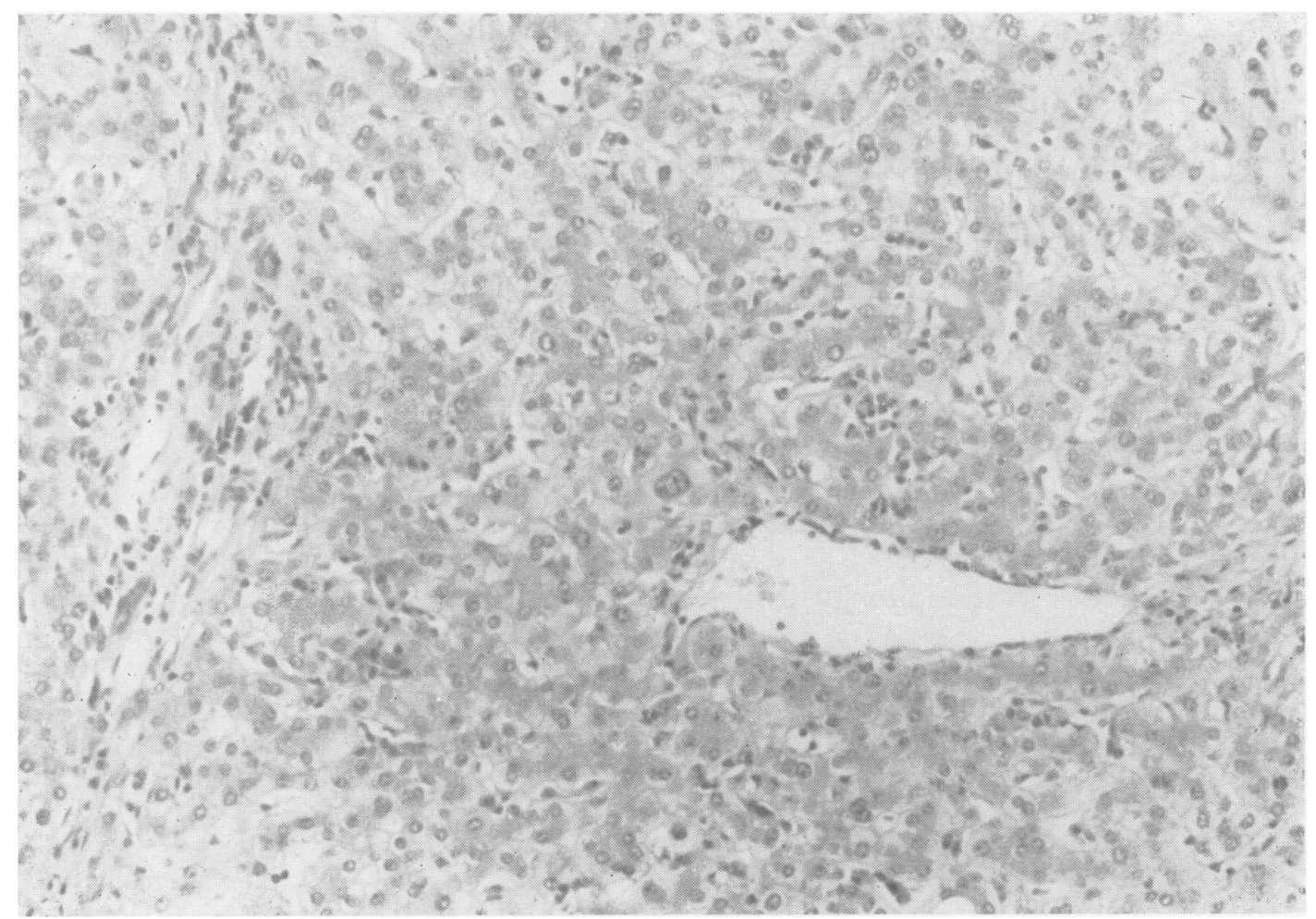

FIG. 1. Case 1. Part of operative liver biopsy. Inflammatory cells are scattered throughout the parenchyma and there is mild portal inflammation. H. \& E. $\times 160$.

antibiotics. The institution of salizopyrine in $1966 \mathrm{im}$ proved the diarrhoea, but has not altered the frequency or severity of the cholangitis. He is at present able to carry out his normal work, but if the cholangitis continues further surgical exploration will be undertaken. Neither liver nor spleen is palpable and there are no stigmata of liver disease.

CASE 2 In 1955, 11 months after her second pregnancy, this 26-year-old housewife developed diarrhoea which lasted six months and recurred on several occasions until 1958 since when she has had no further bowel symptoms. Sigmoidoscopy and barium enema in 1966 showed chronic inactive ulcerative colitis involving the distal colon. She was not receiving steroids or salizopyrine for diarrhoea and has only taken paregoric.

In September 1965 she developed aphthous ulcers of the mouth and vagina. In November she began to itch and in December an attack of epigastric pain and diarrhoea lasted one day. Jaundice appeared in January 1966 with pale stools and dark urine, but without fever or pain. The liver was palpable $3 \mathrm{~cm}$. below the costal margin, the spleen was not palpable. Biochemical investigations (Table II) showed a cholestatic picture. Percutaneous liver biopsy showed periportal fibrosis and an acute inflammatory portal zone lesion with oedema. Heavy cholestasis was largely periportal, suggesting an intra- hepatic cause, but the other features favoured large duct obstruction. A laparotomy was performed, when the common bile duct was found to be thickened and its lumen extremely narrowed. It contained granular pultaceous material. An operative cholangiogram and subsequent $\mathrm{T}$ tube cholangiogram showed the common duct to be narrowed (Fig. 2). There was narrowing of the right and left main hepatic ducts close to their origins with a proximal dilatation. One or two of their major subdivisions showed a tendency towards beading and there was a lack of normal branching. The gall bladder was removed. A child's size T-tube was inserted in the common duct and removed 10 days after the operation.

Histological examination of the contents of the common duct showed granulation tissue with proliferating biliary epithelium but no tumour (Fig. 3). The gall bladder, which contained no stones, showed mild acute and chronic inflammatory changes. The wall was oedematous and the muscle coat thickened. There were several small lymphoid aggregates and numerous plasma cells. Non-specific reactive changes were seen in a lymph node from the porta hepatis. The histological appearances in an operative liver biopsy were similar to those in the needle biopsy but with fewer neutrophils in the inflammatory exudate and an occasional focal aggregate of lymphocytes. Concentric fibrosis was evident around many of the smaller bile ducts (Fig. 4). 


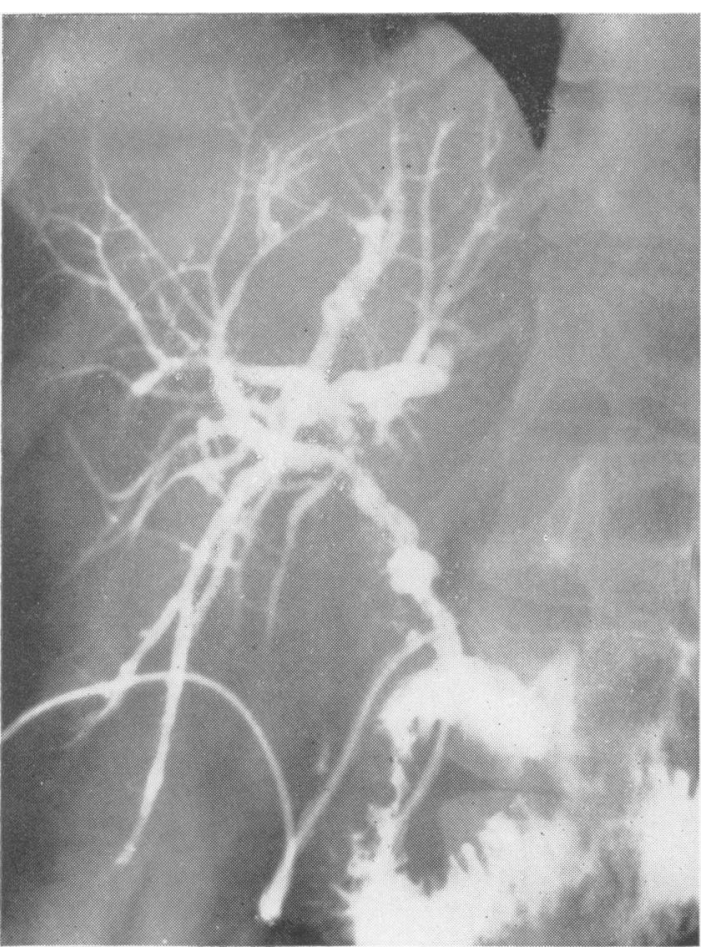

FIG. 2.

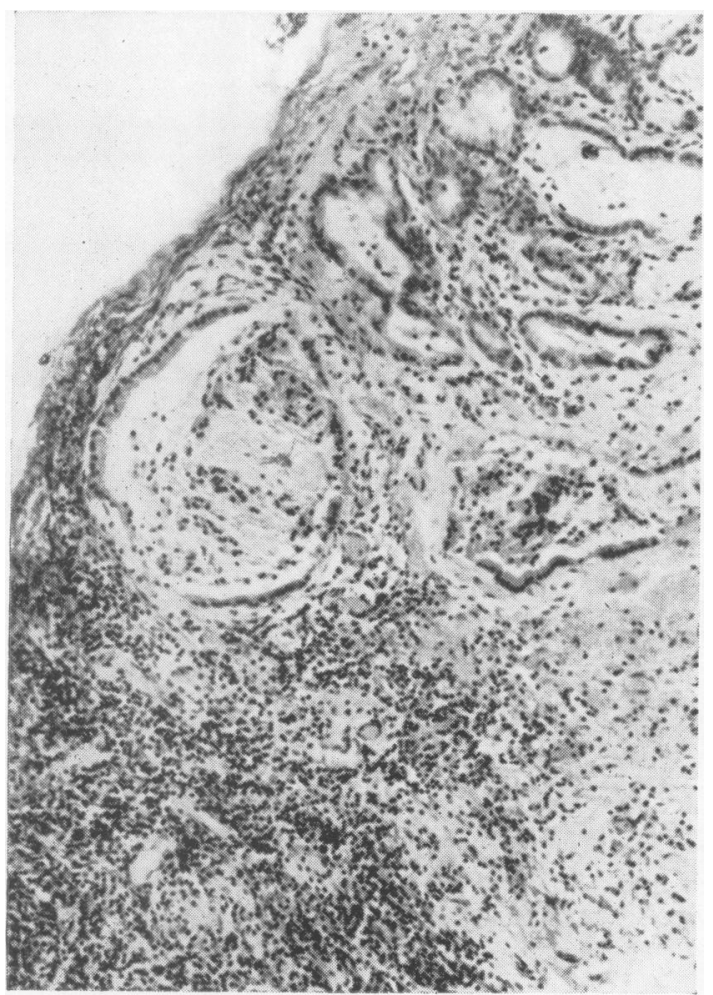

FIG. 3.

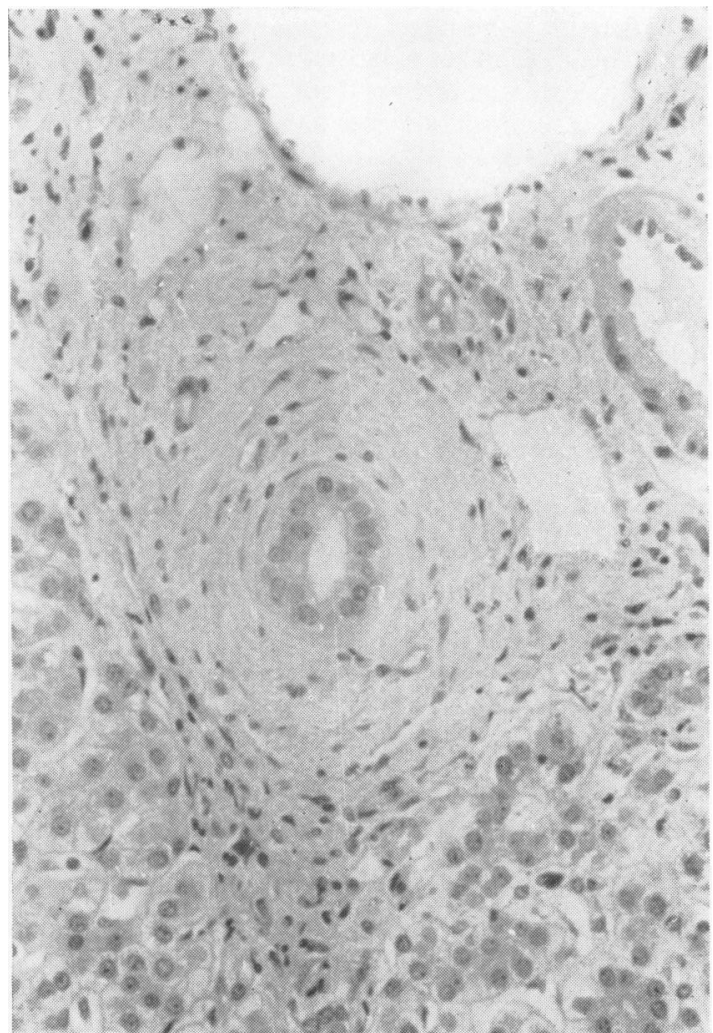

FIG. 4.

FIG. 2. Case 2. T tube cholangiogram showing narrowing of the right and left main hepatic ducts close to their origins, with proximal dilatation. One or two of the major subdivisions show a tendency towards beading and there is a lack of normal branching.

FIG. 3. Case 2. Material from bile duct showing dilated and proliferated ducts and chronic inflammatory infiltration. H. \& E. $\times 106$.

FIG. 4. Case 2. High-power view of part of portal zone from wedge biopsy of liver, showing concentric fibrosis around a small bile duct (chronic pericholangitis). $H . \& E$. $\times 216$. 
The patient is now free of jaundice and suffers only from itching. The liver is not palpable and there are no other physical signs of liver disease. The serum alkaline phosphatase and transaminase levels remain elevated.

CASE 3 In 1950, this 29-year-old housewife had four admissions to hospital for bloody diarrhoea and a diagnosis of ulcerative colitis was made. She had further attacks intermittently until 1960 . In 1966, although she had no bowel symptoms, sigmoidoscopy and barium enema showed severe changes of chronic ulcerative colitis throughout the colon and in the terminal ileum.

In 1961, the patient developed right proptosis for which a corrective operation was performed after negative craniotomy. The proptosis recurred in 1963 and was followed by bilateral exophthalmos and external ocular palsy. ${ }^{131}$ I uptake was normal and protein-bound ${ }^{131}$ I $10.7 \mu \mathrm{g}$. per $100 \mathrm{ml}$. (normal 3 to $8 \mu \mathrm{g}$. per $100 \mathrm{ml}$.). The thyroid gland was slightly enlarged, smooth and not tender. She received neomercazole and thyroxine for three years, but the proptosis has persisted. She is at present clinically euthyroid; the serum level of longacting thyroid stimulator (L.A.T.S.) is normal and there are no thyroid antibodies.

In December 1960 she had a first attack of cholestatic jaundice accompanied by fever. There was no nausea, vomiting, or abdominal pain. Following four recurrences of jaundice and fever, laparotomy was performed in July 1961. The common duct was found to be fibrosed and thickened and an operative cholangiogram showed it to be completely blocked (Fig. 5). The intrahepatic tree was well outlined. There was narrowing of the intrahepatic ducts close to their origin with some proximal dilatation. There was early beading of the inferior subdivisions of the right hepatic duct system, and a lack of normal branching of the hepatic duct system. Choledocho-jejunostomy was performed and the gall bladder was removed.

Histological study of a biopsy of the common bile duct showed much fibrosis, proliferation of biliary epithelium and heavy infiltration with mononuclear cells, some of which had formed aggregates. No tumour was found. The gall bladder showed mild chronic inflammation. There were several small lymphoid aggregates and plasma cells were prominent. A wedge liver biopsy showed fibrosis but no nodules. Bile duct proliferation and neutrophils in portal zones were consistent with large duct disease. In addition, however, there were many mononuclear cells, and some of these had formed aggregates around otherwise normal medium-sized ducts (Fig. 6). There was no cholestasis.

The patient was free of symptoms until 1965 when she had four typical attacks of cholangitis, responding to tetracycline. A percutaneous needle biopsy of liver was taken in April 1966, and showed developing true nodular cirrhosis of biliary pattern (Fig. 7). At this time the serum bilirubin was $1.0 \mathrm{mg}$. per $100 \mathrm{ml}$., alkaline phosphatase $27 \mathrm{~K}$.A. units per $100 \mathrm{ml}$, aspartate transaminase 34 I.U. per litre, serum albumin $3.5 \mathrm{~g}$. and globulin $4 \cdot 1 \mathrm{~g}$. per 100 $\mathrm{ml}$. , and serum cholesterol $176 \mathrm{mg}$. per $100 \mathrm{ml}$.

Tetracycline was continued prophylactically and she was well until September when she again became jaundiced. Sulphatriad was substituted, with relief of the

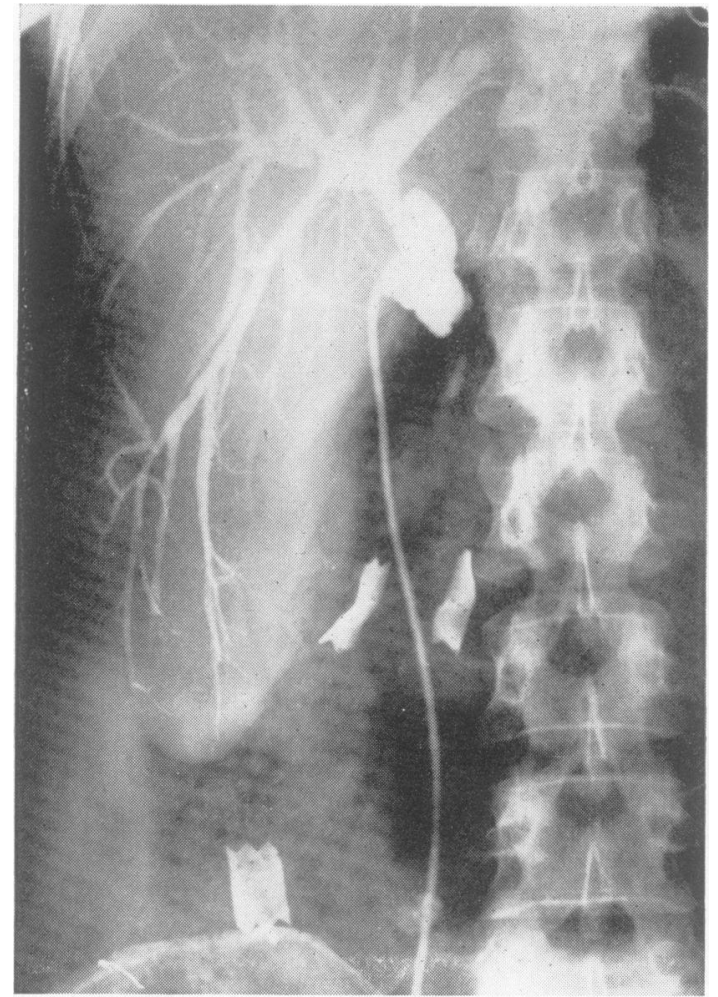

FIG. 5. Case 3. Operative cholangiogram showing the common duct to be completely obstructed. There are strictures of the main intrahepatic ducts close to their origins with proximal dilatation. There is beading of the inferior subdivisions of the right hepatic duct system and a lack of normal branching.

jaundice. She is now well, with no physical signs of liver disease.

CASE 4 In 1952 this 30-year-old schoolmaster had an episode of diarrhoea lasting nine weeks. Barium enema at this time showed a normal pattern. A further attack lasting four months occurred in 1955. Stools were loose but contained no blood. The diarrhoea recurred in 1957, with blood occasionally in the stools, and continued until his death in 1966. Repeated sigmoidoscopies revealed active colitis and barium enemas in 1957 and 1960 showed widespread involvement of the transverse and descending colon as well as part of the ileum.

One week after the onset of diarrhoea in 1955 he became jaundiced for the first time. This was accompanied by pale stools, dark urine, and colicky abdominal pain. The serum bilirubin was $5.1 \mathrm{mg}$. per $100 \mathrm{ml}$., serum alkaline phosphatase $46 \mathrm{~K}$.A. units per $100 \mathrm{ml}$., and serum cholesterol $280 \mathrm{mg}$. per $100 \mathrm{ml}$. Needle biopsy of the liver showed moderate fibrosis, inflammation, and cholestasis consistent with chronic or recurrent biliary disease. Laparotomy was performed and the common bile duct 
FIG. 6. Case 3. Part of wedge liver biopsy. An infiltrate near a bile duct is seen in the expanded and fibrotic portal zone. H. \& E. × 160 .

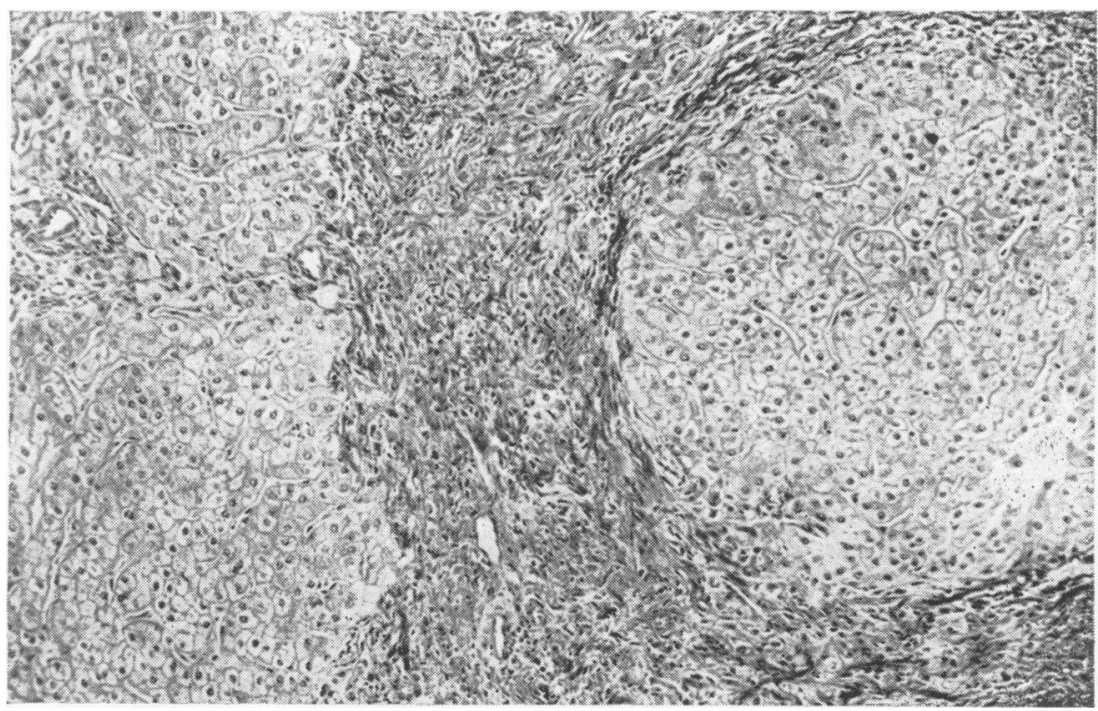

FIG. 7. Case 3. Part of needle liver biopsy. Nodular cirrhosis has developed. Prominent concentric collagen bands around the nodule are characteristic of the biliary aetiology. Trichrome $\times 90$. 

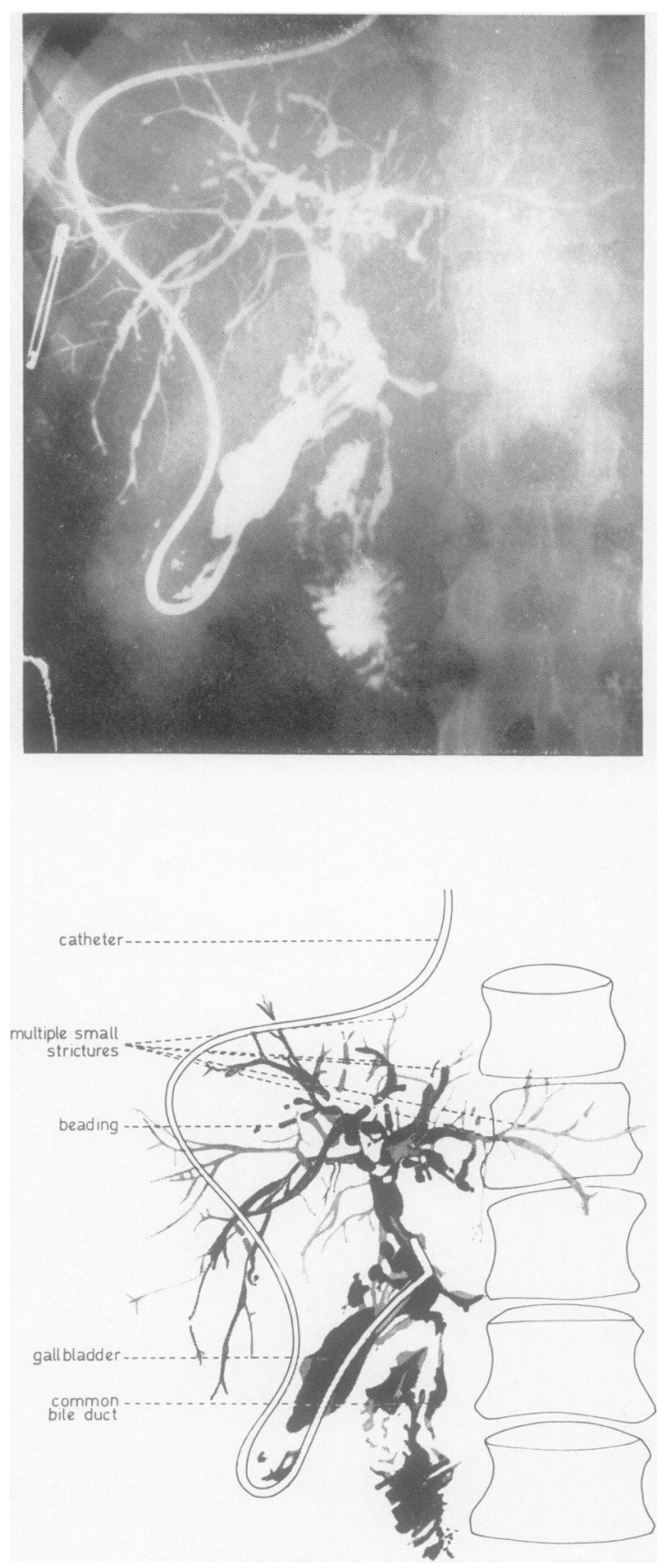

FIG. 8. Case 4. Operative cholangiogram through the gall bladder showing irregular narrowing of the common duct below the origin of the cystic duct. There are multiple strictures of the intrahepatic ducts with beading and a lack of normal branching. found to be a thickened fibrous cord with a hardly discernible lumen. Cholangiography demonstrated diffuse irregular narrowing of the common duct below the origin of the cystic duct, but the dye was still able to pass to the duodenum. The intrahepatic ducts showed a lack of normal branching and multiple strictures with beading (Fig. 8). Cholecysto-jejunostomy was performed and the jaundice was relieved. Histological appearances in a biopsy of the common bile duct were those of chronic inflammation; connective tissue contained proliferated glands and showed focal as well as diffuse infiltration with mononuclear cells. There were smaller numbers of plasma cells and neutrophils. Lymph nodes showed reactive changes and contained many plasma cells.

Cholangitis and jaundice returned three months postoperatively. This was initially relieved in 1957 by repair of the cholecysto-jejunostomy. Jaundice again returned in 1958. High stenosis at the common duct was found at laparotomy in 1959 and cholecystectomy, choledochostomy, and sphincterotomy were performed with relief of jaundice. A bile duct biopsy showed acute and chronic inflammation and squamous metaplasia. The gall bladder was thickened by oedema and muscle hypertrophy rather than fibrosis (Fig. 9). The epithelium was tall and papillary and the lamina propria contained lymphoid aggregates and many plasma cells. Rokitansky-Aschoff sinuses were few. Reactive changes were again seen in the lymph nodes.

The patient continued to have a raised level of serum alkaline phosphatase and impaired B.S.P. excretion, but was free of any symptoms of liver disease until 1966. Needle biopsies of liver performed in 1960 and 1966 showed the effects of chronic biliary disease.

In May 1966 the patient was admitted to hospital with severe anaemia $(4.5 \mathrm{~g} . \%)$ due to hypoprothrombinaemia and an acute exacerbation of colitis for about five days. He was not jaundiced on admission. He was transfused with 10 pints of blood and one week later became jaundiced (serum bilirubin 14 to $20 \mathrm{mg}$., alkaline phosphatase, 100 K.A. units per $100 \mathrm{ml}$.). The jaundice was not affected by steroids or tetracycline, but the patient felt well and was able to continue his work. In September 1966, following a fall, he complained of a painful left shoulder, which showed no abnormality radiologically. He then developed sciatic pain down the right leg, and a full skeletal survey in November 1966 demonstrated multiple osteolytic lesions affecting the ribs, humerus, and pelvis. His condition rapidly deteriorated and he died several weeks later.

At necropsy, extensive healed ulcerative colitis was seen to have involved the entire colon. There were scattered areas where the mucosa appeared polypoid but no intestinal carcinoma was found. The liver $(2,600 \mathrm{~g}$.) was large and dark green with a slightly uneven but neither nodular nor granular surface. Several pale yellow tumour deposits up to $0.3 \mathrm{~cm}$. in diameter were visible on the capsular surface, and deep to the adherent right diaphragm there was a mass, approximately $5 \mathrm{~cm}$. across, of coalescent metastases. Sectioning of the liver revealed fine fibrosis without cirrhosis. Septa were less than $0 \cdot 1 \mathrm{~cm}$. wide. In addition to the deposits of metastatic tumour there was an angular hard grey mass of tumour $3 \mathrm{~cm}$. across involving the main right hepatic duct $1 \mathrm{~cm}$. from 


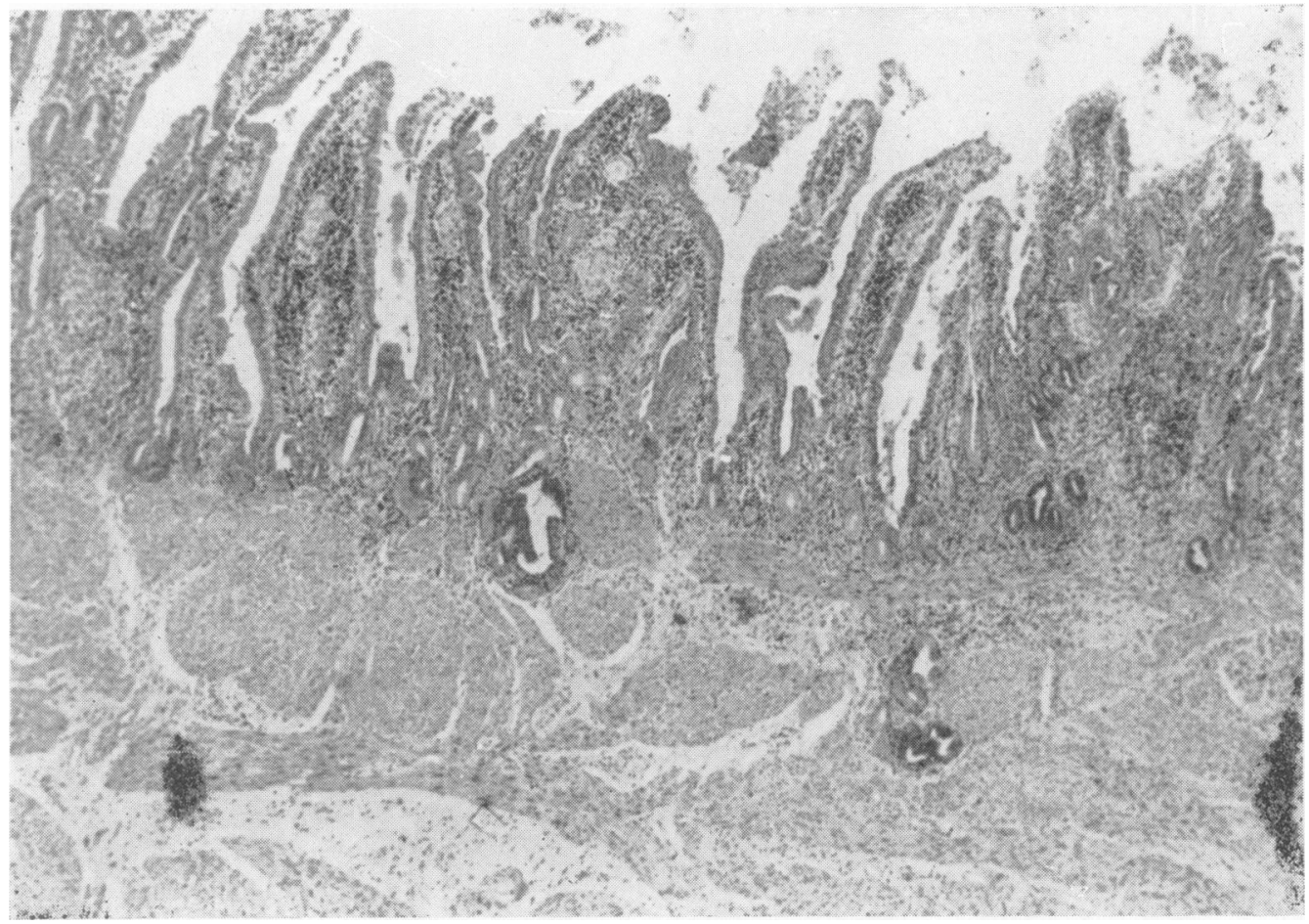

FIG. 9. Case 4. The mucosa of the gall bladder wall is markedly papillary and there is cellular infiltration. The muscle coat is thickened. $H . \& E . \times 40$.

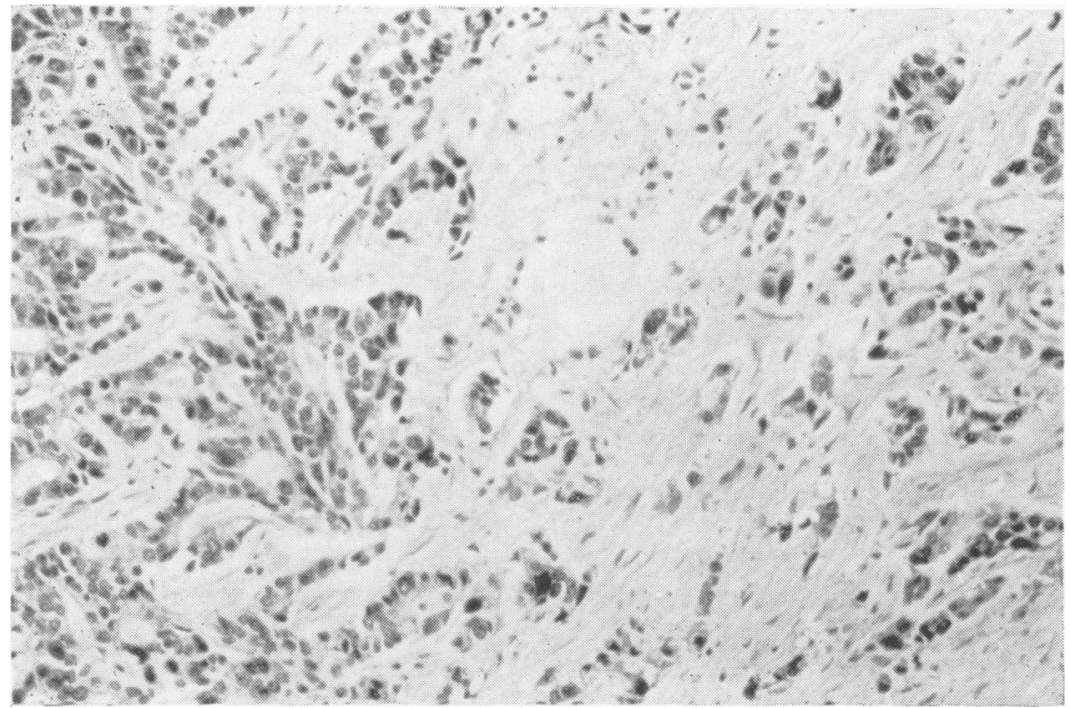

FIG. 10. Case 4. Liver at necropsy, showing a metastasis from the well-differentiated adenocarcinoma of the right hepatic duct. H. \& E. $\times 160$. 


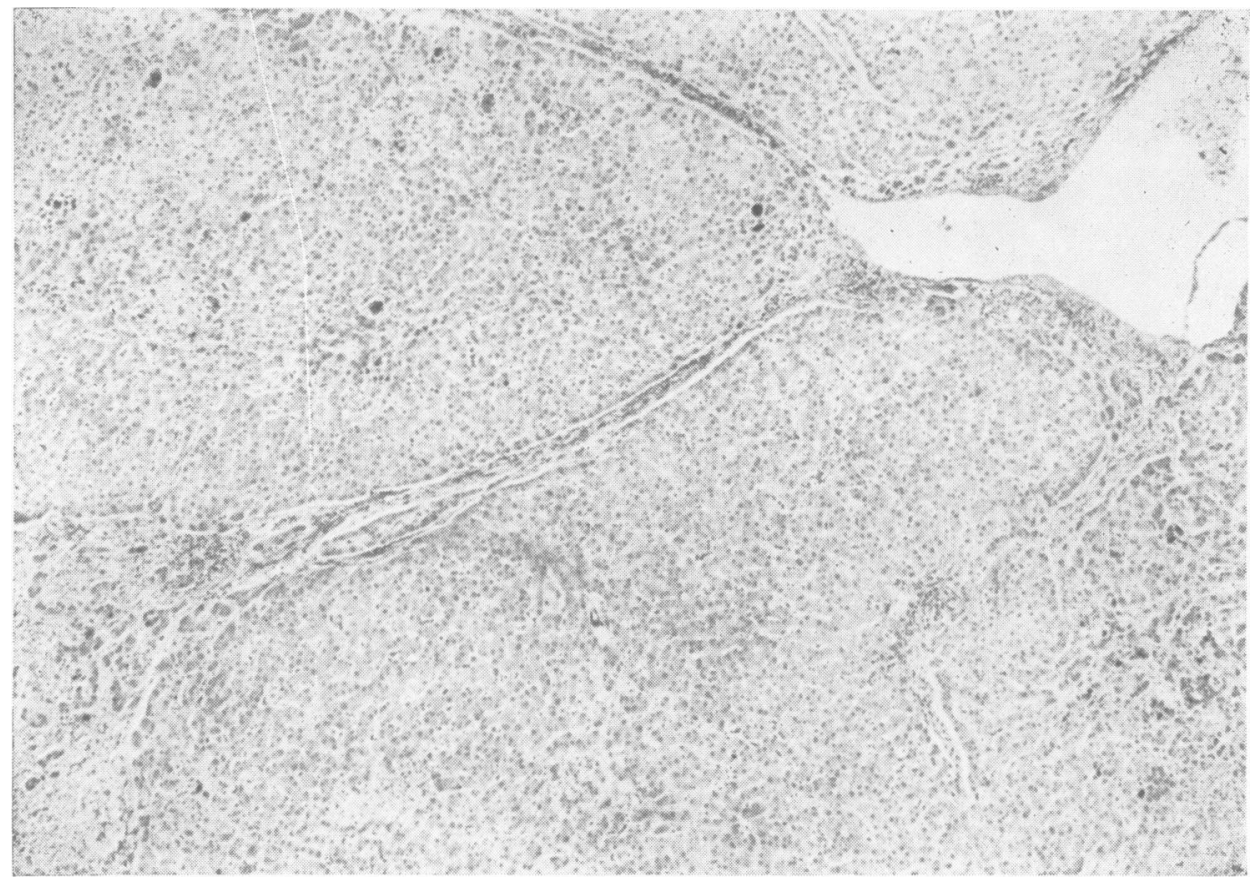

FIG. 11.

Case 4. Liver

at necropsy.

There are

fibrous septa.

No nodules

are seen.

Dark foci

within the

parenchyma

are bile plugs.

Trichrome

$\times 40$.

its junction with the left hepatic duct. The latter was not obstructed. A $2 \mathrm{~cm}$. length of common duct remained, and included the stump of the cystic duct. The common duct was fully patent and soft; its lumen measured $0.5 \mathrm{~cm}$. across and the wall was not more than $0.1 \mathrm{~cm}$. thick. The ampulla of Vater was widely patent and no lesions were found in the pancreas. Metastatic tumour was demonstrated in liver and in several bones but not in hepatic hilar or other lymph nodes. There was bilateral bronchopneumonia.

On histological examination the tumour proved to be a well-differentiated mucus-secreting adenocarcinoma (Fig. 10). The common bile duct remnant was free of tumour and showed neither inflammation nor sclerosis. In the liver, fibrous septa extended from portal zones (Fig. 11) and while in a few places islands of parenchyma appeared isolated by the septa, diffuse nodular cirrhosis was absent. Within the septa there were loose lymphoid aggregates as well as more diffusely distributed acute and chronic inflammatory cells. Bile ducts of interlobular size were diminished in number. Ductules had proliferated. There was intense cholestasis.

\section{SUMMARY OF CLINICAL FEATURES (TABLE I)}

In all four patients, symptoms of colitis preceded the onset of clinical jaundice by one week to 10 years. The jaundice was always of cholestatic type and was accompanied by fever and abdominal pain in cases 1 and 4 and by fever without pain in case 3 . All were explored surgically at the time of their first attack of jaundice. No patient had had previous surgery to the biliary tree. The colitis had a variable relationship to the jaundice. In two it was active (cases 1 and 4) and in the other two it has been inactive for seven and six years respectively. In one case only (case 1) were subsequent attacks of colitis and jaundice related. Treatment of the colitis has been variable. No patient received salizopyrine before the onset of jaundice and only cases 1 and 4 have had it subsequently. Codeine, corticosteroids, and paregoric (case 2) have been the other treatments.

The only operative interference to the biliary tree in case 1 was biopsy of the duct at the first operation. Cholecystectomy and exploration of the common bile duct with subsequent $T$ tube draining were performed in case 2. By-pass operations were performed in cases 3 and 4 and subsequent correction operations for re-stenosis were required in case 4 . The liver was 1 to $2 \mathrm{~cm}$. palpable in one patient (case 4) and a Riedel's lobe was present in another (case 3). The liver is not palpable in the other two patients and in no patient is the spleen palpable. Case 4 was jaundiced for six months before death. No patients had any other stigmata of liver disease except case 4 in whom there was finger clubbing. The only patient with clinical features of any other disease process is case 3 who has bilateral exophthalmos.

One patient only (case 2) has remained free of jaundice and requires no treatment although she still has pruritus. The other three patients have all had further cholangitic episodes. Tetracycline was until 
TABLE I

CLINICAL FEATURES

\begin{tabular}{|c|c|c|c|c|}
\hline & $\begin{array}{l}\text { Case } 1 \\
M, 35\end{array}$ & $\begin{array}{l}\text { Case } 2 \\
F, 37\end{array}$ & $\begin{array}{l}\text { Case } 3 \\
F, 45\end{array}$ & $\begin{array}{l}\text { Case } 4 \\
M, 45\end{array}$ \\
\hline \multicolumn{5}{|l|}{ Ulcerative colitis } \\
\hline Date of onset & 1963 & 1955 & 1950 & \multirow{4}{*}{$\begin{array}{l}1955 \\
\text { Active } \\
\text { No treatment before } \\
\text { 1955; codeine, steroids } \\
\text { (intermittently); no sali- } \\
\text { zopyrine before } 1957 \\
\text { One week }\end{array}$} \\
\hline Activity & Active & Inactive for seven years & Inactive for six years & \\
\hline Treatment & $\begin{array}{l}\text { Codeine, steroids, salizo- } \\
\text { pyrine since } 1966\end{array}$ & Paregoric only & $\begin{array}{l}\text { Not certain; nil for past } \\
\text { six years; no salizopyrine }\end{array}$ & \\
\hline Period between onset of & One year & Ten years & Ten years & \\
\hline $\begin{array}{l}\text { jaundice } \\
\text { Severity of ulcerative colitis at } \\
\text { time of onset of liver disease }\end{array}$ & Active & $\begin{array}{l}\text { Inactive (except for } \\
\text { aphthous ulcers) }\end{array}$ & Inactive & Active \\
\hline $\begin{array}{l}\text { Subsequent attacks of ulcera- } \\
\text { tive colitis and jaundice related }\end{array}$ & Yes & No & No & No \\
\hline \multicolumn{5}{|l|}{ Liver disease } \\
\hline $\begin{array}{l}\text { First attack of jaundice } \\
\text { Symptoms } \\
\text { First operation (diagnostic) }\end{array}$ & $\begin{array}{l}1964 \\
\text { Cholangitic } \\
1964\end{array}$ & $\begin{array}{l}1966 \\
\text { Cholestatic } \\
1966\end{array}$ & $\begin{array}{l}1960 \\
\text { Cholangitic } \\
1961\end{array}$ & $\begin{array}{l}1955 \\
\text { Cholangitic } \\
1955\end{array}$ \\
\hline & $\begin{array}{l}\text { (Laparotomy) } \\
\text { Biopsy of duct }\end{array}$ & $\begin{array}{l}\text { Exploration of common } \\
\text { bile duct, cholecystec- } \\
\text { tomy, } T \text { tube drainage }\end{array}$ & $\begin{array}{l}\text { Choledocho-jejunostomy- } \\
\text { en-y, cholecystectomy }\end{array}$ & Cholecysto-jejunostomy \\
\hline Subsequent jaundice & $1965,1966(\times 6)$ & Nil & 1965,1966 & \multirow{3}{*}{$\begin{array}{l}\text { 1955, 1956, 1957, 1958, } \\
1959,1966 \text { (terminal) } \\
\text { No treatment for liver } \\
\text { 1959-May 1966; steroids, } \\
\text { antibiotics terminally } \\
\text { Nil required 1959-1966; } \\
\text { no effect terminal chole- } \\
\text { stasis }\end{array}$} \\
\hline Medical treatment & $\begin{array}{l}\text { Steroids, ampicillin, tetra- } \\
\text { cycline }\end{array}$ & Nil & $\begin{array}{l}\text { Tetracycline, sulphatriad } \\
\text { recently }\end{array}$ & \\
\hline Efficacy of medical treatment & $\begin{array}{l}\text { Poor. Recurrent cholan- } \\
\text { gitis, jaundice, and diar- } \\
\text { rhoea }\end{array}$ & $\begin{array}{l}\text { No further jaundice, mild } \\
\text { pruritis }\end{array}$ & $\begin{array}{l}\text { Fair; cholangitis con- } \\
\text { trolled by antibiotics, } \\
\text { ineffective prophylactical- } \\
\text { ly }\end{array}$ & \\
\hline
\end{tabular}

TABLE II

SERUM BIOCHEMICAL VALUES AT TIME OF INITIAL JAUNDICE AND MOST RECENT VALUES ${ }^{1}$

\begin{tabular}{|c|c|c|c|c|c|c|c|}
\hline \multirow[t]{2}{*}{ Test } & \multicolumn{2}{|l|}{ Case 1} & \multicolumn{2}{|l|}{ Case 2} & \multirow{2}{*}{$\frac{\text { Case } 3}{1966}$} & \multicolumn{2}{|l|}{ Case 4} \\
\hline & May 1964 & 1966 & January & 1966 & & May 1955 & 1966 \\
\hline $\begin{array}{l}\text { Bilirubin (mg./100 ml.) } \\
\text { Alkaline phosphatase }\end{array}$ & $12 \cdot 5$ & $0.5-7.6$ & 6 & $0.8-1.0$ & $1 \cdot 0-4 \cdot 0$ & $5 \cdot 1$ & $0 \cdot 8-16 \cdot 5$ \\
\hline $\begin{array}{l}\text { (King Armstrong units } / 100 \mathrm{ml} .) \\
\text { Glutamic oxaloacetic transaminase (I.U./l.) } \\
\text { Albumin (g./100 ml.) } \\
\text { Globulin (g./100 ml.) } \\
\text { Cholesterol (mg. } / 100 \mathrm{ml} .)\end{array}$ & $\begin{array}{l}20 \\
20 \\
4 \cdot 6 \\
3 \cdot 1\end{array}$ & $\begin{array}{c}34-65 \\
17-31 \\
4 \cdot 4 \\
3 \cdot 6 \\
230\end{array}$ & $\begin{array}{c}104 \\
56 \\
3 \cdot 9 \\
2 \cdot 7 \\
230\end{array}$ & $\begin{array}{l}26-63 \\
31-37\end{array}$ & $\begin{array}{c}27-56 \\
34-52 \\
3 \cdot 5 \\
4 \cdot 1 \\
175\end{array}$ & $\begin{array}{c}46 \\
56 \\
3 \cdot 4 \\
4 \cdot 6 \\
280\end{array}$ & $\begin{array}{l}35-115 \\
40-75 \\
4 \cdot 0 \\
3 \cdot 2 \\
280\end{array}$ \\
\hline
\end{tabular}

${ }^{1}$ Minimum and maximum values in 1966.

recently effective in the control of such attacks in one patient (case 3). Sulphatriad controlled the last attack. Both corticosteroids and antibiotics have been used in case 1 but with only moderate success. Before the onset of jaundice six months before his death, case 4 had had no further jaundice since his last operation in 1959. Terminal jaundice was unaffected by corticosteroids and antibiotics.

\section{SUMMARY OF SPECIAL INVESTIGATIONS}

LIVER FUNCTION TESTS (TABLE II) In three patients (cases $1,2,3$ ) at the time of presentation the serum biochemistry was consistent with cholestatic jaundice. The serum alkaline phosphatase was moderately raised in two patients (cases 1 and 4) and in only one patient (case 2) exceeded 50 K.A. units per $100 \mathrm{ml}$. Serum aspartate transaminase values were minimally elevated in all cases and the serum cholesterol values were normal except in case 4 where they were minimally elevated.

Since the initial surgery, the alkaline phosphatase values have fluctuated but remained raised. Aspartate transaminase values have also remained slightly elevated. These increases were unrelated to the presence or absence of jaundice. The institution of corticosteroids and/or antibiotics has not changed serum phosphatase or transaminase levels. Terminally, the serum bilirubin and serum alkaline phosphatase rose to very high levels in case 4 . Serum cholesterol values have remained at normal levels in one case (case 4 ) where it was consistently minimally 
elevated. Serum albumin levels have been maintained at normal levels and the globulin levels were usually a little elevated.

HAEMATOLOGY In all four patients the E.S.R. was persistently raised in the range 30 to $60 \mathrm{~mm}$. in one hour (Westergren). Higher values were sometimes seen during episodes of cholangitis. All patients have been able to maintain normal haemoglobin levels except one patient (case 4) who has been repeatedly iron deficient. The white cell counts have usually ranged from 5 to 12,000 per c.mm. with a normal differential. During episodes of jaundice or cholangitis, the values have usually remained within this range but occasionally (case 1) have risen to up to $18,000 \mathrm{c} . \mathrm{mm}$. with a polymorphonuclear leucocytosis.

CHOLANGIOGRAPHY Operative cholangiography was performed in three patients at their initial laparotomy and all showed both intra- and extrahepatic duct involvement. The common duct was completely obstructed in case 3 ; it was diffusely narrowed but patent in case 2 and in case 4 it was irregularly narrowed below the origin of the cystic duct. The intrahepatic ducts in all three cases showed similar changes but to varying degrees. They were generally narrowed and there was a lack of normal branching. In some areas the ducts were regularly narrowed, and, especially in case 4 , this narrowing has gone on to stricture formation, which, with some degree of proximal dilatation, produced the appearance of beading. In cases 2 and 3 definite strictures were only seen close to the origin of the main intrahepatic ducts, whilst in case 4 the strictures extended into the periphery.

ANTIBODY STUDIES (TABLE III) All patients were investigated for the presence of organ specific antibodies (thyroid, stomach, and adrenal) and nonorgan specific antibodies (mitochondrial, antinuclear factor, rheumatoid factor, L.E. cells, Coombs test).

All tests were negative in case 1 . In case 2 there was a trace of thyroid specific antibodies only. There were no thyroid specific antibodies in case 3 but the rheumatoid factor was positive (Latex positive, sheep cell agglutination positive $1 / 250$ ). The antinuclear factor was weakly positive $(1 / 8)$ and mitochondrial antibodies were weakly positive $(1 / 16)$. All tests were negative in case 4 except smooth muscle antibodies and mitochondrial antibodies, which although not present in 1965 , were weakly positive (1/16 and 1/4) in 1966.

SUMMARY OF HISTOLOGICAL FINDINGS (TABLE IV) In all four cases a chronic fibrosing inflammatory pro-
TABLE III

SERUM ANTIBODY STUDIES, 1966

Case 1 Case 2 Case 3 Case 4

\begin{tabular}{|c|c|c|c|c|c|}
\hline \multicolumn{6}{|l|}{ Organ specific } \\
\hline Thyroid & - & \pm & - & & - \\
\hline Stomach & - & 二 & - & & - \\
\hline Muscle & - & - & - & & + \\
\hline \multicolumn{6}{|l|}{ Non-organ specific } \\
\hline Antinuclear factor & - & - & $\pm(1 / 8)$ & & - \\
\hline $\begin{array}{l}\text { Sheep cell agglutina- } \\
\text { tion }\end{array}$ & - & - & $+(1 / 250)$ & & - \\
\hline Slide latex test & - & - & + & & - \\
\hline Mitochondrial & & & & 1965 & 1966 \\
\hline $\begin{array}{l}\text { (Fluorescent) } \\
\text { (C.F.T.) }\end{array}$ & - & - & $\stackrel{+}{1 / 16}$ & - & $\stackrel{+}{\frac{1}{4}, 1 / 16}$ \\
\hline Coombs test & - & - & - & & - \\
\hline L.E. cells & - & - & - & & - \\
\hline
\end{tabular}

cess was seen to involve the common bile duct. There were some poorly defined aggregates of lymphocytes. Plasma cells were common. Eosinophils were only identified in the biopsy from case 1 . In the second duct biopsy from case 4 neutrophils were numerous. In this biopsy the epithelium showed squamous metaplasia, and in all cases there was epithelial proliferation. No carcinoma was found in any of the specimens.

Sections of gall bladder were examined in three of the cases and showed inflammatory changes. Lymphoid aggregates were present and the mucosa was infiltrated with plasma cells. In case 2 there were many neutrophils. Oedema and muscular hypertrophy were noted in the sections from cases 2 and 4 and in the latter the mucosa showed striking papillary overgrowth. No specific abnormalities were detected in the several lymph nodes seen; all showed reactive changes.

The liver presented a variety of histological features. In case 1 there was a subacute hepatitis unlike that caused by the infective hepatitis group of viruses, together with considerable cholestasis but no other indication of biliary disease. By the following year this hepatitis had regressed. In case 2 the initial biopsy suggested a combination of extra- and intrahepatic obstruction to the biliary tree. Subsequent wedge biopsy appearances were again obstructive, but in addition there were small lymphoid aggregates in portal zones and concentric fibrosis was noted around small bile ducts. Typical peribiliary lesions of primary biliary cirrhosis were absent. Case 3 also had liver changes of biliary obstruction with the addition of lymphoid aggregates, some of them peribiliary, and within five years there was progression to nodular cirrhosis of biliary pattern. In the last case there was similarly progressive liver disease. In this case alone no wedge biopsy was taken, and the histological diagnosis during life was more difficult. At necropsy there was hepatic fibrosis, 
TABLE IV

SUMMARY OF HISTOLOGICAL FINDINGS

\begin{tabular}{|c|c|c|c|c|c|}
\hline Case & Onset of Jaundice & Date of Specimen & Specimen & Figure & Histology \\
\hline 1 & May 1964 & $\begin{array}{l}\text { July } 1964 \\
\text { July } 1964 \\
\text { July } 1965\end{array}$ & $\begin{array}{l}\text { Bile duct } \\
\text { Liver (wedge) } \\
\text { Liver (needle) }\end{array}$ & $\overline{1}$ & $\begin{array}{l}\text { Chronic inflammation } \\
\text { Subacute hepatitis with cholestasis } \\
\text { Fibrosis only }\end{array}$ \\
\hline \multirow[t]{4}{*}{2} & January 1966 & January 1966 & Liver (needle) & - & $\begin{array}{l}\text { Fibrosis, portal inflammation, and periportal } \\
\text { cholestasis }\end{array}$ \\
\hline & & $\begin{array}{l}\text { February } 1966 \\
\text { February } 1966\end{array}$ & $\begin{array}{l}\text { Bile duct contents } \\
\text { Gall bladder }\end{array}$ & - & $\begin{array}{l}\text { Chronic inflammation } \\
\text { Acute and chronic inflammation, Lymphoid } \\
\text { aggregates }\end{array}$ \\
\hline & & February 1966 & Lymph node & - & Reactive hyperplasia \\
\hline & & February 1966 & Liver (wedge) & 4 & $\begin{array}{l}\text { Fibrosis, cell infiltration with aggregates, chronic } \\
\text { 'pericholangitis', and cholestasis }\end{array}$ \\
\hline \multirow[t]{3}{*}{3} & December 1960 & July 1961 & Bile duct & - & Chronic inflammation \\
\hline & & $\begin{array}{l}\text { July } 1961 \\
\text { July } 1961\end{array}$ & $\begin{array}{l}\text { Gall bladder } \\
\text { Liver (wedge) }\end{array}$ & $\overline{6}$ & $\begin{array}{l}\text { Mild chronic inflammation with lymphoid aggregates } \\
\text { Fibrosis, acute and chronic portal inflammation with } \\
\text { lymphoid aggregates and 'pericholangitis', and duct } \\
\text { proliferation }\end{array}$ \\
\hline & & April 1966 & Liver (needle) & 7 & Biliary cirrhosis \\
\hline \multirow[t]{9}{*}{4} & May 1955 & May 1955 & Liver (needle) & - & Fibrosis, portal inflammation, and cholestasis \\
\hline & & June 1955 & Bile duct & - & Chronic inflammation \\
\hline & & June 1955 & Lymph nodes & - & Reactive hyperplasia \\
\hline & & January 1959 & Bile duct & 一 & $\begin{array}{l}\text { Acute and chronic inflammation with squamous } \\
\text { metaplasia }\end{array}$ \\
\hline & & January 1959 & Gall bladder & 9 & $\begin{array}{l}\text { Papillary change, oedema, muscle hypertrophy and } \\
\text { inflammation with lymphoid aggregates }\end{array}$ \\
\hline & & January 1959 & Lymph nodes & - & Reactive hyperplasia \\
\hline & & June 1960 & Liver (needle) & 一 & $\begin{array}{l}\text { Portal fibrosis and inflammation, and ductular } \\
\text { proliferation }\end{array}$ \\
\hline & & May 1966 & Liver (needle) & - & $\begin{array}{l}\text { Fibrosis, early nodule formation, and peripheral } \\
\text { cholestasis }\end{array}$ \\
\hline & & November 1966 & Necropsy & 10,11 & $\begin{array}{l}\text { Hepatic fibrosis and early nodule formation } \\
\text { Adenocarcinoma of } R \text {. hepatic duct with metastases } \\
\text { in liver and bone; remnant of common bile duct } \\
\text { normal }\end{array}$ \\
\hline
\end{tabular}

evidence of chronic biliary disease, and carcinoma of the right hepatic duct.

\section{DISCUSSION}

The requisites for the diagnosis, of sclerosing cholangitis are (1) diffuse generalized involvement of the extrahepatic ducts; (2) absence of previous biliary surgery; (3) absence of gall stones; (4) exclusion of carcinoma of the ducts by reasonably long follow up (Holubitsky and McKenzie, 1964; Warren, Athanassiades, and Monge, 1966). Other criteria include progressive icterus without pathological evidence of a malignant neoplasm (Bartholomew et al., 1963). Radiologically, diffuse narrowing of the common bile duct may be seen (Manesis and Sullivan, 1965). Patient 4 had developed a carcinoma by the time of necropsy. This tumour, however, was clearly a late complication since persistent jaundice was only present for six months after an anicteric period of seven years. Furthermore, the tumour did not involve the sclerosed common bile duct. A longer follow up will be necessary in cases 1 and 2 before carcinoma can be excluded with certainty. The incomplete involvement of the extrahepatic ducts in one of our cases (case 4) does not militate against the diagnosis of sclerosing cholangitis, for Warren et al. (1966) found patchy involvement of the bile ducts in $29 \%$ of cases.

Sclerosing cholangitis is an uncommon association of ulcerative colitis. Warren and co-workers (1966), in a series of 1,474 patients with ulcerative colitis, found only 12 with accompanying sclerosing cholangitis. The presence of atypical cholestatic features suggests the diagnosis, although on purely clinical grounds it is not possible to differentiate sclerosing cholangitis from intrahepatic biliary disease or other large duct pathology. The present cases could only be diagnosed at laparotomy. As with the other forms of biliary disease accompanying colitis, in particular pericholangitis (Mistilis, Skyring, and Goulston, 1965a), there was no relation between the severity and duration of the ulcerative colitis and the episodes of jaundice. Once the diagnosis has been established the future clinical course will depend on the extent and progression of the sclerosing process and the efficacy of surgery in the relief of any large duct obstruction. Recurrent cholangitis with jaundice was the principal clinical feature in our long-term follow up, cholestasis per se occurring less frequently. 
Primary sclerosing cholangitis has been associated with fibrosing lesions elsewhere in the body such as retroperitoneal fibrosis (Schwartz and Dale, 1958), mediastinal fibrosis (Hawk and Hazard, 1959), Riedel's struma (Woolner, McConahey, and Beahrs, 1957), and retro-orbital tumours (Haché, Utz, and Woolner, 1962; Arnott and Greaves, 1965). There was only one patient in the present series (case 3 ) with retro-orbital tumours. She subsequently developed bilateral exophthalmos. Clinically she is euthyroid and all tests of thyroid function are normal except for a slightly raised protein-bound iodine $^{131}$. Thyroid histology is, however, not available and Riedel's thyroiditis cannot be excluded with certainty.

The liver function tests did not aid in the differentiation of an intra- and/or extra-hepatic cause for the cholestasis. The persistently elevated alkaline phosphatase level, irrespective of the presence or absence of jaundice, was similar to that described in pericholangitis (Mistilis et al., 1965a) although the levels in pericholangitis are usually higher.

Serum antibody tests gave variable, and at the present time inexplicable, results. The smooth muscle antibody is present in a wide range of liver disease and the mitochondrial immunofluorescence is by no means specific for primary biliary cirrhosis (Doniach, Roitt, Walker, and Sherlock, 1966). These tests are, however, negative in secondary biliary cirrhosis.

If the sclerosis affected the extrahepatic ducts only a dilated intrahepatic biliary tree would be expected. Instead, operative cholangiography showed the intrahepatic ducts to be narrowed and they are presumably involved in the same process. The beading would appear diagnostic. Percutaneous cholangiography was not attempted but the narrowed intrahepatic ducts would probably have caused this procedure to fail. Operative cholangiography was also difficult but the introduction of the catheter through the gall bladder, as in case 4, may facilitate this procedure.

Fibrosis and non-specific inflammation has been previously reported in the bile ducts (Roberts, 1955; Goldgraber and Kirsner, 1960; Bartholomew et al., 1963; Holubitsky and McKenzie, 1964). An abundance of tissue eosinophils (Bartholomew et al., 1963) and necrosis of the duct tissue (Goldgraber and Kirsner, 1960) has also been noted. The present patients showed similar changes of non-specific chronic inflammation, lymphoid aggregates, and in one case a few scattered eosinophils in the cellular infiltrate.

In three of our four cases there was inflammation of the gall bladder wall. The changes probably represented part of the spectrum of biliary tract involvement. Gallstones were not found at laparotomy in any of the three cases. Schwartz and Dale (1958) reported inflamed or thickened gall bladders in eight of 19 patients with sclerosing cholangitis but in only two of the eight were calculi found. The appearances were not those of the cholecystitis typically associated with cholelithiasis; inflammation was mild, there was little new fibre formation, and there were few Rokitansky-Aschoff sinuses. Lymphoid aggregates and abundant plasma cells were striking features. In case 4 papillary change of the mucosa, oedema of the wall, and muscular hypertrophy made an unusual combination. Association of ulcerative colitis, sclerosing cholangitis, and distinctive non-calculous gall bladder disease has previously been reported by Goldgraber and Kirsner (1960).

None of the liver biopsies showed the picture of uncomplicated large duct biliary obstruction but in some, notably in case 2 , the resemblance was close and probably reflects the combination of intrahepatic and extrahepatic disease. In biopsies taken late in the course of the liver disease some of the changes may have been secondary to biliary surgery. There was no histological evidence of primary biliary cirrhosis.

The cause of sclerosing cholangitis is not known. Bacterial, viral, allergic, or toxic factors have been invoked (Stauffer et al., 1965). The association of sclerosing cholangitis with other diseases considered to have an autoimmune basis has led to the suggestion that it may be part of a systemic disorder (Smith and Loe, 1965). Drug therapy, in particular with sulphonamides, has also been considered as a possible aetiological or aggravating factor (Stauffer et al., 1965). None of these factors was proven in the present cases.

Treatment consists of decompression of the biliary tree to relieve any obstruction. Cholangiography should always be performed at operation, to demonstrate the extent of both the extra- and intrahepatic biliary duct involvement. A biopsy of the duct should be taken to confirm the diagnosis. If the obstruction is complete it is relieved by resection of a stricture or a bypass procedure. When the obstruction is incomplete but involves the whole of the duct, $T$ tube drainage may be the treatment of choice (Smith and Loe, 1965). Of our two patients who had generalized incomplete obstruction, one (case 2) has done very well following $\mathrm{T}$ tube drainage and the other (case 1), who was not given the benefit of $T$ tube drainage, has done badly. The $\mathrm{T}$ tube, or preferably a $Y$ tube, has the added advantage that postoperative cholangiograms can be performed to assess the state of the ducts. The gall bladder, if possible, should be left intact, so that if obstruction recurs it may be utilized for a bypass procedure. 
Eventually it may become necessary to resect most of the duct and gall bladder.

Medical treatment is useful for the control of cholangitis episodes, when antibiotics alone or combined with corticosteroids are usually effective. It is, however, ineffective when given prophylactically to prevent further cholangitis or jaundice. There is no evidence that medical therapy with corticosteroids alters the course of the disease process. Similar observations have been made in pericholangitis (Mistilis, Skyring, and Goulston, 1965b). Persistent jaundice or recurrent cholangitis may necessitate further surgery.

The prognosis of sclerosing cholangitis is considerably better than originally reported. If the large duct obstruction can be relieved liver cell function is well preserved and patients may remain asymptomatic for periods of more than five years. A biliary cirrhosis may develop (case 3), although, as in case 4, cirrhosis had not developed even 11 years after the original diagnosis. The prognosis is probably better than in primary biliary cirrhosis and it resembles that of a traumatic (postoperative) biliary stricture. The only death (case 4) was due to hepatic duct carcinoma. This complication has been reported in ulcerative colitis with and without accompanying biliary disease (Stauffer et al., 1965; Rankin et al., 1966). It has been described in patients considered initially to have sclerosing cholangitis and subsequently within one to five years found to have an associated carcinoma. Its development in case 4 was a terminal event.

The present cases had many of the clinical and pathological features of pericholangitis. Vinnick and Kern (1963) entertained the diagnosis of pericholangitis only in the presence of a normal biliary tree but Smith and Loe (1965) described pericholangitis occurring together with sclerosing cholangitis and speculated on a relationship between the two conditions. Stauffer et al. (1965) reported narrowed or thickened ducts and also gall bladder disease in cases of ulcerative colitis with portal zone inflammation. Two of our four cases had the histological lesions of pericholangitis, and in these, as well as in a third case, intrahepatic involvement of the biliary tree was demonstrated on cholangiography. Since pericholangitis is patchy, the fourth case may also have lesions in the liver. The major bile ducts, gall bladder, and liver can be involved in a similar pathological process in an individual case. Sclerosing cholangitis may thus be one component of a syndrome in which pericholangitis represents the intrahepatic duct lesion.

The disease process may not affect the whole intra- and extrahepatic biliary tree in every case, for not all cases with pericholangitis also have primary sclerosing cholangitis. For example, Boden, Rankin, Goulston, and Morrow (1959) were able to exclude obstruction to the biliary tree in six of seven patients with ulcerative colitis and pericholangitis, and Hellstrom and Perez-Stable (1966) described sclerosing cholangitis involving only intrahepatic ducts. Nevertheless, the concept of a single disease process involving all or any part of the biliary apparatus has the merit of simplifying the problem of cholestasis in ulcerative colitis. The clinical and biochemical features of pericholangitis (Mistilis et al., 1965b) are similar to those of our cases and there is also little difference in the response to steroid or antibiotic therapy.

\section{SUMMARY}

The clinical and pathological features of four cases of sclerosing cholangitis with ulcerative colitis are presented. The diagnosis can only be made at laparotomy. On clinical and laboratory findings the differentiation of sclerosing cholangitis from other intrahepatic biliary disease or large duct pathology is impossible.

The common duct is seen as a thickened fibrous cord with a markedly reduced lumen. Operative cholangiography and duct biopsy should be performed to confirm the diagnosis. Cholangiography localizes the site of any obstruction, demonstrates the extent of the intra- and extrahepatic duct involvement, and the appearance of beading appears to be diagnostic. The pathological changes in the bile duct are not specific in themselves. Gall bladder lesions were seen in three of the cases. The liver presented a variety of histological lesions including pericholangitis. The present study shows sclerosing cholangitis to be a general disease of the biliary tree that can affect both the intra- and extrahepatic ducts as well as the gall bladder. The findings also suggest that sclerosing cholangitis and pericholangitis may be part of a single disease process involving all or part of the biliary apparatus in ulcerative colitis.

The cause of sclerosing cholangitis is not known but none of the usual factors invoked were proven in the present cases. There was no relationship between either the severity or duration of the colitis and jaundice. Serum antibody studies gave variable and at the present time inexplicable results.

The prime requisite of treatment is decompression of the biliary tree to relieve any obstruction. Medical treatment is of use in the control of cholangitic episodes but is ineffective in altering the course of the disease process. Corticosteroids are of limited value. The prognosis is, however, considerably better than originally reported, patients frequently remaining asymptomatic for a number of years. One patient 
has developed a biliary cirrhosis but the only death was due to a complicating hepatic duct carcinoma.

We are grateful to Dr. D. Doniach and I. Roitt for performing the antibody studies; to Dr. Clifford Hawkins for his referral and help with case 3 and to Professor C. V. Harrison for the early pathological sections of case 4 . We thank the Royal Australian College of Physicians for a grant to one of us (M.E.C.T.).

\section{REFERENCES}

Arnott, E. J., and Greaves, D. P. (1965). Orbital involvement in Riedel's thyroiditis. Brit. J. Ophthal., 49, 1-5.

Bartholomew, L. G., Cain, J. C., Woolner, L. B., Utz, D. C., and Ferris, D. O. (1963). Sclerosing cholangitis. Its possible association with Riedel's struma and fibrous retroperitonitis. Report of two cases. New Engl. J. Med., 269, 8-12.

Boden, R. W., Rankin, J. G., Goulston, S. J. M., and Morrow, W. (1959). The liver in ulcerative colitis. The significance of raised serum-alkaline-phosphatase levels. Lancet, 2, 245-248.

Doniach, D., Roitt, I. M., Walker, J. G., and Sherlock, S. (1966). Tissue antibodies in primary biliary cirrhosis, active chronic (lupoid) hepatitis, cryptogenic cirrhosis and other liver diseases and their clinical implications. Clin. exp. Immunol., 1, 237-262.

Goldgraber, M. B., and Kirsner, J. B. (1960). Chronic granulomatous cholecystitis and chronic fibrosing choledochitis associated with chronic ulcerative colitis. A case report. Gastroenterology, 38, 821-828.

Haché, L., Utz, D. C., and Woolner, L. B. (1962). Idiopathic fibrous retroperitonitis. Surg. Gynec. Obstet., 115, 737-744.

Hawk, W. A., and Hazard, J. B. (1959). Sclerosing retroperitonitis and sclerosing mediastinitis. Amer. J. clin. Path., 32, 321-334.

Hellstrom, H. R., and Perez-Stable, E. C. (1966). Retroperitoneal fibrosis with disseminated vasculitis and intrahepatic sclerosing cholangitis. Amer. J. Med., 40, 184-187.
Holdsworth, C. D., Hall, E. W., Dawson, A. M., and Sherlock, S. (1965). Ulcerative colitis in chronic liver disease. Quart. J. Med., 34, 211-227.

Holubitsky, I. B., and McKenzie, A. D. (1964). Primary sclerosing cholangitis of the extrahepatic bile ducts. Canad. J. Surg., 7, 277-283.

Kimmelstiel, P., Large, H. L., Jr., and Verner, H. D. (1952). Liver damage in ulcerative colitis. Amer. J. Path., 28, 259-289.

Manesis, J. G., and Sullivan, J. F. (1965). Primary sclerosing cholangitis. Arch. intern. Med., 115, 137-139.

Mistilis, S. P. (1965). Pericholangitis and ulcerative colitis. I. Pathology, etiology, and pathogenesis. Ann. intern. Med. 63, 1-16.

—, Skyring, A. P., and Goulston, S. J. M. (1965a). Pericholangitis and ulcerative colitis. II. Clinical aspects. Ibid., 3, 17-26.

,,$----(1965 \mathrm{~b})$. Effect of long-term tetracycline therapy, steroid therapy and colectomy in pericholangitis associated with ulcerative colitis. Aust. Ann. Med., 14, 286-294.

Rankin, J. G., Skyring, A. P., and Goulston, S. J. M. (1966). Liver in ulcerative colitis: obstructive jaundice due to bile duct carcinoma. Gut, 7, 433-437.

Roberts, J. M. (1955). Stenosing cholangitis. West. J. Surg., 63, 253-259.

Schwartz, S. I., and Dale, W. A. (1958). Primary sclerosing cholangitis ; review and report of six cases. Arch. Surg., 77, 439-451.

Smith, M. P., and Loe, R. H. (1965). Sclerosing cholangitis: review of recent cases reports and associated diseases and four new cases. Amer. J. Surg., 110, 239-246.

Stauffer, M. H., Sauer, W. G., Dearing, W. H., and Baggenstoss, A. H. (1965). The spectrum of cholestatic hepatic disease. J. Amer. med. Ass., 191, 829-837.

Vinnick, I. E., and Kern, F., Jr. (1963). Liver disease in ulcerative colitis. Arch. intern. Med., 112, 41-49.

Warren, K. W., Athanassiades, S., and Monge, J. I. (1966). Primary sclerosing cholangitis. A study of forty-two cases. Amer. J. Surg., 111, 23-38.

Woolner, L. B., McConahey, W. M., and Beahrs, O. H. (1957). Invasive fibrous thyroiditis (Riedel's struma). J. clin. Endocr., 17, 201-220. 